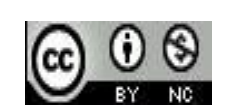

Jurnal Pendidikan Bahasa dan Sastra Indonesia is licensed under

A Creative Commons Attribution-Non Commercial 4.0 International Licens

\title{
Patologi Sosial dalam Novel Rembulan Tenggelam di Wajahmu Karya Tere Liye
}

\author{
Mila Megawulandari ${ }^{1)}$, Zainal Rafli ${ }^{2)}$, Saifur Rohman ${ }^{3}$ ) \\ ${ }^{1)}$ Mahasiswa Program Pendidikan Bahasa, Pascasarjana, Universitas Negeri Jakarta \\ Email: milamegawulandari_pb15s2@mahasiswa.unj.ac.id \\ ${ }^{2)}$ Dosen Program Pendidikan Bahasa, Pascasarjana, Universitas Negeri Jakarta \\ Email:zainalrafli@unj.ac.id \\ ${ }^{3)}$ Dosen Program Pendidikan Bahasa, Pascasarjana, Universitas Negeri Jakarta \\ Email: saifur_rohman2000@yahoo.com
}

\begin{abstract}
Abstrak: Penelitian ini bertujuan untuk menggetahui bentuk-bentuk Patologi sosial dalam Novel Rembulan Tenggelam di Wajahmu Karya Tere Liye. Metode yang digunakan dalam penelitian ini adalah metode kualitatif dengan teknik analisis isi. Data yang menjadi objek penelitian ini adalah kutipan dan dialog yang mengidentifikasikan bentuk-bentuk patologi sosial dalam Novel Rembulan Tenggelam di Wajahmu karya Tere Liye yang ditinjau dari sosiologi sastra. Penelitian ini dilakukan sebagai refleksi sosial untuk menghadapi masalah sosial salah satunya adalah tentang masalah penyakit masyarakat atau dalam istilah ilmu sosiologi disebut patologi sosial. Berdasarkan hasil analisis, ditemukan bahwa bentuk-bentuk patologi sosial dalam Novel Rembulan Tenggelam di Wajahmu berupa kriminalitas, perjudian, minuman keras, korupsi, dan prostitusi.
\end{abstract}

Kata Kunci: patologi sosial; novel; analisis isi; sosiologi sastra

\section{PENDAHULUAN}

Patalogi sosial adalah semua tingkah laku yang bertentangan dengan norma kebaikan, stabilitas lokal, pola kesederhanaan, moral, hak milik, solidaritas keluarga, hidup rukun bertetangga, disiplin, kebaikan, hukum, formal. Dengan kata lain, patologi sosial membahas mengenai masalah sosial yang berkaitan dengan penyakit masyarakat (Kartono, 2015:1). Sejalan dengan itu menurut Jamaludin (2016:16) patologi menyebabkan kerugian bagi individu tersebut atau orang lain sehingga dapat menimbulkan keresahan individu atau sosial.

Dalam realitasnya, masalah sosial sekarang ini sudah merusak nilai moral, susila, luhur, dan religius, serta beberapa aspek dasar yang terkandung di dalamnya, baik hukum tertulis maupun tidak tertulis. Dari segi materiil, baik individual, kolektif, maupun negara acap kali terpaksa harus menerima beban kerugian. Begitu juga dari segi immaterial, yaitu tidak adanya rasa aman, ketentraman hidup, dan kedamaian. Pada akhirnya, keadaan ini semakin menambah banyaknya masalah-masalah sosial. Masalah tersebut umumnya berkaitan dengan kebutuhan sandang, pangan, papan. Kesulitan beradaptasi dengan perubahan menyebabkan kebingungan dan kecemasan, sehingga dapat memicu konflik, baik yang bersifat internal maupun eksternal. Hal tersebut membuat manusia melakukan pola tingkah laku yang menyimpang dari pola umum, melakukan apa saja demi kepentingan sendiri, bahkan dapat merugikan orang lain, sehingga mereka melakukan tindakan seperti kriminalitas, perjudian, korupsi, minuman keras, narkoba, prostitusi, pornografi, geng motor, ataupun premanisme yang merupakan bentuk-bentuk dari patologi sosial (penyakit masyarakat).

Seperti halnya di Indonesia, berita tentang bentuk-bentuk patologi sosial seperti tidak ada habisnya. Tindakan kriminal, perjudian, minuman keras, korupsi, sampai prostitusi selalu terjadi. Seperti kejadian di Sleman Yogyakarta. Menurut Anugrah (2019) terdapat 90 orang menjadi tersangka dari 46 kasus yang diungkap aparat Polda DIY selama Operasi Penyakit Masyarakat. Operasi tersebut digelar aparat Polda DIY beserta jajaran kepolisian resor (polres) selama 10 hari, mulai dari 24 Juni sampai 3 Juli lalu. Terdapat 46 kasus yang diungkap tersebut, masing-masing ada tujuh kasus prostitusi; 13 kasus perjudian; 25 kasus peredaran minuman keras ilegal; dan satu kasus premanisme. (Anugrah, 2019). 
Kondisi inilah yang ingin digambarkan Tere Liye dalam novel Rembulan Tenggelam di Wajahmu karya Tere Liye sebagai realita yang terjadi pada masyarakat Indonesia. Berdasarkan penjelasan di atas, banyak disiplin ilmu yang melakukan penelitian mengenai patologi sosial termasuk yang berhubungan dengan sastra sebagai salah satu kajian yang diteliti. Masalah tentang patologi sosial ini banyak terdapat pada tema-tema karya sastra, khususnya novel. Patologi sosial juga pernah dijadikan sebagai teori dalam artikel yang ditulis oleh Basri, dkk untuk meneliti novel Mimi Lan Minuta karya Remi Silado yang berjudul Patologi Sosial dalam Novel Mimi Lan Minuta Karya Remi Silado (Basri, Moh Hasan, Sunarti Mustamar, Sri Ningsih, 2013). Namun pada penelitian ini memiliki perbedaaan yaitu dari objek novelnya sehingga menghasilkan bentuk patologi sosial yang berbeda pula.

Selain itu, novel Rembulan Tenggelam di Wajahmu juga pernah diteliti oleh Yamin Deswal dengan judul Kepribadian Tokoh dalam Novel Rembulan Tenggelam di Wajahmu (Yasmin, 2016). Namun penelitian tersebut membahas dari segi psikologi sastra sedangkan penelitian ini membahas dari sosiologi sastra dan berbeda pula teori pengkajiannya, sehingga penelitian ini memiliki novelty dari penelitian sebelumnya. Begitu menariknya masalah ini membuat peneliti tertarik untuk melakukan penelitian yang membahas bagaimana bentuk-bentuk patologi sosial dalam novel Rembulan Tenggelam di Wajahmu karya Tere Liye berdasarkan sosiologi sastra.

\section{METODE}

Penelitian ini mengunakan ialah pendekatan kualitatif dengan metode analisis isi (content analysis). Pendekaan ini digunakan untuk memahami suatu fenomena yang berkaitan dengan latar belakang subjek penelitian secara mendalam (Moleong: 2011:7). Dalam penelitian ini fakta tersebut adalah patologi sosial yang digambarkan dalam Novel Rembulan Tenggelam di Wajahmu karya Tere Liye ditinjau dari kajian sosiologi sastra. Metode ini dilakukan untuk memperoleh penafsiran dari isi penelitian yang disampaikan dalam bentuk tabel analisis.

Sumber data primer penelitian ini adalah Novel Rembulan Tenggelam di Wajahmu karya Tere Liye. Sementara sumber data sekunder yang digunakan dalam penelitian ini adalah buku-buku, jurnal, artikel, internet, dan bahan-bahan lainnya yang berhubungan dengan penelitian dan memudahkan peneliti dalam proses analisis.. Data sekunder digunakan sebagai data pelengkap yang dapat membantu proses klarifikasi atau konfirmasi terhadap data primer. Adapun langkah-langkah penelitian ini antara lain: (a) Mencari tema yang relevan dalam kehidupan masyarakat untuk menjadi bahan kajian penelitian dan menemukan novel yang relevan dengan tema yang diinginkan, (b) Selanjutnya peneliti membaca secara intensif serta mempelajari secara cermat alur cerita Novel Rembulan Tenggelam di Wajahmu Karya Tere Liye, (d) Membuat tabel instrument pengumpulan data, (e) Mengidentifikasi dan mencatat kutipan-kutipan kalimat sesuai dengan masalah dalam penelitian, (f) Mengklasifikasikan data yang sudah diidentifikasi berdasarkan aspek-aspek dalam rumusan masalah penelitian dalam tabel analisis, (g) melakukan inferensi (menyimpulkan) serta menyesuaikan dengan teori relevan, serta (h) Melakukan analisis dan interpretasi data.

Penelitian ini menggunakan pendekatan sosiologi sastra menurut pandangan Wellek dan Warren. Menurut Wellek dan Warren terdapat tiga jenis pendekatan yang berbeda dalam sosiologi sastra. Pertama, sosiologi pengarang. Masalah yang berkaitan di sini adalah dasar ekonomi produksi sastra, latar belakang sosial, status pengarang dan ideologi pengarang yang terlihat dari berbagai kegiatan pengarang di luar karya sastra. Kedua, sosiologi isi karya sastra. Yang mempermasalahkan isi karya sastra, tujuan, serta hal-hal lain yang tersirat dalam karya sastra itu sendiri dan yang berkaitan dengan masalah sosial. Ketiga, sosiologi sastra yang mempermasalahkan pembaca dan pengaruh sosial karya sastra. Sejauh mana sastra ditentukan atau tergantung dari latar sosial, perubahan dan perkembangan sosial, adalah pertanyaan yang termasuk dalam ketiga jenis permasalahan di atas. (Wellek dan Werren, 1993:111-112)

Penelitian ini memfokuskan kajiannya dengan telaah klasifikasi kedua yaitu memfokuskan telaah pada sosiologi isi karya sastra. Mempermasalahkan isi karya sastra, tujuan, serta hal-hal lain yang tersirat dalam karya sastra itu sendiri dan yang berkaitan dengan masalah-masalah sosial dalam hal ini berkaitan dengan ilmu patologi sosial. Mengkaji secara mendalam setiap unsur sosial yang ada dalam teks sehingga ditemukan tujuan dari pengarang menulis karya sastra tersebut. Hal itu penting karena seringkali pengarang menulis karya dengan tujuan-tujuan tertentu dan pesan-pesan moral yang hendak disampaikan kepada pembaca.

Penelitian ini merupakan penelitian kepustakaan dengan teknik analisis isi, maka penelitian ini tidak terikat oleh tempat atau lokasi tertentu. Dengan kata lain, penelitian ini dapat dilakukan dimana saja. Adapun waktu pelaksanaan penelitian ini dilaksanakan mulai bulan Februari 2019.

\section{HASIL DAN PEMBAHASAN}

Segala tindakan atau perilaku yang tidak sesuai dengan nilai-nilai dan norma yang berlaku dalam masyarakat dianggap sebagai bentuk penyimpangan. Bentuk-bentuk penyimpangan ini, apabila terus berkembang akan menyebabkan timbulnya penyakit sosial dalam masyarakat. Sementara itu bentuk-bentuk penyakit sosial yang ada dalam masyarakat bermacam-macam, beberapa diantaranya yaitu kriminalitas, perjudian, minuman keras, korupsi, dan pelacuran. Bentuk-bentuk penyakit masyarakat ini dalam istilah ilmu sosiologi disebut patologi sosial. Berikut ini hasil temuan penelitian patologi sosial dalam novel Rembulan Tenggelam di Wajahmu karya Tere Liye.

\section{Bentuk Patologi Sosial: Kriminalitas}

Menurut pandangan sosiologi kriminalitas dapat diartikan sebagai semua bentuk tingkah laku yang melanggar 
norma-norma sosial, serta merugikan dan mengganggu keselamatan masyarakat, baik secara ekonomis, politis, maupun sosiaal-psikologis (Burlian, 2016;128). Berdasarkan teori tersebut kriminalitas masuk dalam bentuk patologi sosial. Dalam pembahasan kriminalitas dikelompokan menjadi beberapa bagian, salah satunya kriminalitas menurut bentuk dan jenisnya. Kriminalitas menurut bentuk dan jenisnya yaitu perampokan, penipuan, pencuriaaan, kekerasan, dan sebagainya (Burlian, 2016: 130). Dalam novel Rembulan Tenggelam di Wajahmu karya Tere Liye ada salah satu tokoh bernama Rehan atau Ray, dia termasuk tokoh yang sering melakukan tindak kriminal. Perilakunya sangat buruk selama di panti asuhan tersebut bahkan ketika ia berada di luar panti, ia juga melakukan tindak kriminal. Ia sering melakukan tindak kriminal seperti mencuri dan mencopet yang dapat dilihat pada kutipan berikut.

"Paket-paket kiriman? Itu juga dicurinya. Semalam ketika dua belas penghuni Panti tertidur nyenyak, Rehan pelan-pelan masuk ke kamar tempat kiriman hadiah lebaran itu ditumpuk. Penjaga Panti terlelap, maka dengan mudah Rehan mencuri baju koko, sarung, dan kopiah." (Liye,2018:14)

\begin{abstract}
"Kemudian mulai belajar mencopet di angkutan umum, masih kecil-kecilan. Naik lagi sedikit, mulai berani mencuri di ruko-ruko terminal. Barang apa saja, sepanjang bisa dijual dan menyumpal perutnya yang kosong." (Liye, 2018:53)
\end{abstract}

Pada kutipan tersebut tergambarkan adanya bentuk patologi sosial kriminalitas, yaitu mencuri dan mencopet. Pengarang menggambarkan tokoh Rehan, seorang anak yatim piatu yang dibesarkan di panti asuhan, namun ia berani mencuri paket-paket kiriman lebaran seperti baju koko, sarung, dan kopiah saat anak-anak panti dan penjaga panti sedang tertidur lelap. Lalu, ia juga berani mencopet mulai di angkutan umum sampai berani mencuri di rukoruko terminal. Barang-barang yang ia curi di ruko-ruko tersebut dijual dan hasilnya bisa untuk membeli makanan yang enak karena di Panti makanannya terbatas.

Pada penelitian ini sejalan dengan kasus patologi sosial dari artikel penelitian Moh. Hasan Basri, Sunarti Mustamar, Sri Ningsih dalam judul Analisis Patologi Sosial dalam Novel Mimi Lan Mintuna karya Remy Sylado dalam bentuk patologi sosial kriminalitasnya. Namun, bentuk kriminal dari penelitian tersebut berupa Pembunuhan, Pelanggaran seks dan pemerkosaan, Perampasan, Pengancaman, intimidasi, dan pemerasan, perdangangan gelap, penculikan, dan perdagangaan manusia, sedangkan dalam penelitian ini novel Rembulan Tenggelam di Wajahmu Karya Tere Liye hanya menggambarkan bentuk kriminalitas berupa pencurian, pencopetan, dan kekerasan (fisik dan seks).

\section{Bentuk Patologi Sosial: Perjudian}

Perjudian menurut Kartono (2015: 58) adalah pertaruhan dengan sengaja, yaitu mempertaruhkan satu nilai atau sesuatu yang dianggap bernilai dengan menyadari adanya risiko dan harapan tertentu pada peristiwa-peristiwa, permainan pertandingan, perlombaan, dan kejadian yang tidak atau belum pasti hasilnya. Berdasarkan definisi tersebut, perjudian merupakan bentuk patologi sosial. Perjudian dikatakan patologi sosial karena perbuatan tersebut mempertaruhkan satu nilai atau sesuatu yang dianggap bernilai dengan menyadari adanya risiko dan harapan tertentu pada peristiwa-peristiwa, permainan pertandingan, perlombaan, dan kejadian yang tidak atau belum pasti hasilnya. Hal tersebut melanggar norma yang berlaku di masyarakat. Pada novel Rembulan Tenggelam di Wajahmu karya Tere Liye ini, terdapat salah satu bentuk patologi sosial yaitu perjudian. Hal ini digambarkan oleh pengarang lewat tokoh Rehan. Ketika tokoh Rehan ini berada di luar panti, ia menghabiskan waktunya untuk berjudi di lepau-lepau terminal yang dapat dilihat pada kutipan berikut.

\section{"Uangnya? Habis untuk bermain-main di sudut terminal. Juga ikut-ikutan duduk di lepau-lepau terminal. Sekecil itu dia sudah belajar berjudi." (Liye, 2018:14) \\ "Menggunakan uangnya untuk bermain-main. Memuaskan diri. Dan tentu saja semakin suka berjudi." (Liye, 2018:38)}

Kutipan di atas menggambarkan bentuk perjudian yang dilakukan oleh Rehan, seorang anak yatim piatu yang dibesarkan di panti. Walau ia anak panti asuhan, tetapi ia sering dipekerjakan secara paksa oleh penjaga panti. Tempat kerja yang dituju Rehan adalah di terminal. Di terminal, Rehan bukan bekerja melainkan berjudi. Ia mulai belajar berjudi karena di sudut-sudut terminal tersebut sering diadakan kegiatan perjudian. Pada akhirnya ia ketagihan berjudi, ia mempertaruhkan uangnya demi mendapat uang yang lebih banyak lagi sehingga ia bisa memuaskan hawa nafsunya dan ketika dia merasakan kemenangan saat berjudi maka dia semakin suka berjudi.

Bentuk patologi sosial perjudian ini juga dianalisis oleh Novi Nurcahyanti, Hari Satrijono, dan Furoidatul Husniah dalam artikelnya yang berjudul Patologi Sosial dalam Wacana Lagu Karya Slank Pada Album Plur Tahun 2004. Pada artikel ini menggambarkan bentuk patologi sosial perjudian melalui sebuah lirik. Lirik tersebut menjelaskan bahwa di Indonesia banyak mafia judi namun bisa menyogok polisi sehingga kegiatannya masih tetap berjalan. Bentuk patologi sosial perjudian yang menjadi pembeda dalam penelitian ini yaitu perjudian dilakukan oleh orangorang menengah ke bawah, termasuk Rehan, seorang anak yatim piatu.

\section{Bentuk Patologi Sosial: Minuman Keras}

Burian (2012:175) menyatakan bahwa definisi minuman keras adalah segala yang memabukkan, temasuk obat-obat 
yang terlarang lainnya. Mengkonsumsi minuman keras adalah suatu perilaku minum-minuman keras yang dilakukan oleh seorang atau sekelompok orang untuk mencari kesenangan atau kenikmatan karena efek-efek dari minuman alkohol tersebut. Apalagi jika diminum dalam takaran berlebih bisa mengakibatkan peminumnya menjadi mabuk dan tidak terkontrol. (Wilis, 2005:156). Dalam novel ini kegiatan meminum minuman keras dilakukan oleh Ray dan Gembong Preman. Tempat terjadinya berada di lepau-lepau terminal, ruko-ruko pedagang china yang disertai dengan kegiatan patologi sosial lainnya yaitu perjudian.

"Kau mau saja disuguhi minuman keras. Berjudi sambil tertawa-tawa. Lantas pulang dengan uang sekantong plastik sambil mabuk." (Liye, 2018: 64)

\begin{abstract}
"Ya, malam itu, saat bulan sabit bersinar amat elok, di lorong gang pertokoan yang tertutup dari cahaya apapun, tiga orang tidak dikenalinya datang menyergap. Buas. Mengibaskaan tiga pisau tajam berkilat. Dia melawan sekuat tenaga. Tubuhnya yang kekar dan berisi. Tapi apadaaya kekuataan fisik itu? dia sedang mabuk. Mabuk kemenangan, mabuk minuman keras. Pisau belati itu beringas menusuk perut, paha, dan seluruh tubuhnya. Tubuhnya terjerembab bermandikan darah di atas tong sampah." (Liye, 2018: 64-65)
\end{abstract}

Dari kutipan di atas pengarang menceritakan Ray saat itu sedang berjudi. Ia mengalami tuah yang membuatnya terus menang. Sambil berjudi ia meminum minuman keras yang disuguhi oleh bandar judi di sana. Dengan kemenangannya, lantas ia pulang dengan mabuk kemenangan dan mabuk minuman keras. Namun dibalik kemenangannya ada yang tidak suka. Oknum bandar judi menyuruh tukang pukul untuk menghabisi Ray. Akhirnya Ray tidak bisa melawan karena ia sedang mabuk dan ia pun tertusuk pisau pelati yang diarahkan ke tubuhnya.

Peredaran miras sudah semakin tidak terkontrol. Hal tersebut juga diceritakan oleh pengarang dalam novel Rembulan Tenggelam di Wajahmu ini. Ray sebagai tokoh anak-anak bisa dengan mudah mendapatkan minuman keras. Ia mulai meminum minuman keras pada saat ia berjudi. Ia menyekal botol minuman keras pada malam hari di lepaulepau terminal atau ruko-ruko dekat terminal sambil berjudi. Pada penelitian ini sejalan dengan penelitian yang dilakukan oleh Syarif dalam artikel penelitiannya berjudul Masalah dan Solusi Patologi Sosial Di Kota Tangerang Selatan. Dalam penelitiannya minuman keras di Kota Tangerang Selatan sudah semakin tidak terkontrol dan kian membahayakan generasi muda di kota Tangerang. Artikel yang ditulis Syarif ini dibuktikan dengan mewawancarai salah satu warga di kota Tangerang. Menurut warga di sana tidak adanya kontrol yang ketat dari pemerintah membuat minuman keras beredar sampai ke toko-toko kecil. Biasanya, setiap Sabtu malam banyak anak muda yang sengaja berkumpul di pinggir jalan sambil mengonsumsi minuman keras, khususnya di Jalan Kertamukti, Pisangan, Ciputat.
Selanjutnya akses untuk mendapat minuman keras sangat mudah sehingga setiap sabtu malam anak-anak muda di sana sengaja berkumpul di pinggir jalan sambil menyekal botol minuman keras berbagai merek.

\section{Bentuk Patologi Sosial: Korupsi}

Burlian (2016:160) menyatakan korupsi adalah tingkah laku individu yang menggunakan wewenang dan jabatan guna mengeruk keuntungan pribadi yang merugikan kepentingan umum dan negara. Tindakan korupsi tidak pernah ada habisnya. Pelaku korupsi tidak hanya masyarakat menengah ke bawah namun juga masyarakat menengah ke atas. Oleh karena itu korupsi merupakan salah satu bentuk patologi sosial. Pada novel Rembulan Tenggelam di Wajahmu karya Tere Liye ini terdapat salah satu bentuk patologi sosial korupsi. tindakan korupsi diceritakan pengarang melalui tokoh penjaga panti dan Koh Cheu. Berikut adalah kutipan yang mewakili salah satu bentuk patologi sosial yaitu korupsi.

"Kau benar sekali menuduhnya mengambil semua sumbangan yang diberikan. Dikorup." (Liye, 2018:68)

Kutipan di atas menggambarkan bentuk patologi sosial korupsi. Kutipan tersebut menggambarkan tindak korupsi yang dilakukan oleh penjaga panti. Penjaga panti mengambil semua uang para dermawan untuk kepentingan dirinya sendiri.

Selain penjaga panti yang melakukan korupsi, pada novel ini juga diceritakan ada tokoh lain yang melakukan korupsi, yaitu Koh Cheu.

\section{“Menyuap pejabat, menyelundupkan barang- barang illegal, merusak harga di pasar dengan monopoli dari praktik bisnis liciknya." (Liye, 2018:377)}

Korupsi yang dilakukan oleh Koh Cheu yaitu dengan cara menyuap pejabat, menyelundupkan barang-barang illegal, merusak harga di pasar dengan monopoli dari praktik bisnisnya. Ia dengan licik melakukan perbuatan tersebut demi menyukseskan imperium bisnisnya.

Selanjutnya yang digambarkan oleh pengarang yang melakukan korupsi adalah Ray. Ketika Ray sudah memiliki kegemilangan, ia berusaha untuk membalas dendam. Ia pun melakukan korupsi dengan memanfaatkan isu politik tingkat tinggi hinggga rush besar-besaran di bank swasta akhirnya ia berhasil mengambil secara paksa bisnis Mr. liem. Hal tersebut dapat dillihat dari kutipan berikut.

\footnotetext{
"Ketika ia berhasil mengambil alih secara paksa bisnis keuangan Mister Liem. Melalui serangkaian permainan keuangan canggih, memanfaatkan isu politik tingkat tinggi, desas desus yang membuat panik, hingga rush besar-besaran di bank swasta itu." (Liye, 2018: 393)
} 
Dari kutipan-kutipan tersebut, isi novel ini diketahui terdapat kasus korupsi dilakukan oleh tiga tokoh, yaitu korupsi dilakukan oleh penjaga panti, Koh Cheu dan Ray. Penjaga panti mengambil uang dari para dermawan untuk kepentingan naik hajinya sendiri. Lalu Koh Cheu menyelundupkan barang-barang ilegal demi keuntungan bisnisnya, dan Ray mengambil secara paksa bisnis Mr.Liem melalui serangkaian permainan keuangan canggih, memanfaatkan isu politik tingkat tinggi, desas desus yang membuat panik, hingga rush besar-besaran di bank swasta. Semua yang diceritakan oleh pengarang dalam novel Rembulan Tenggelam di Wajahmu ini merupakan suatu tindak pidana korupsi, sesuai dengan teori dari Kartono dan Burlian tentang definisi korupsi.

Kasus korupsi dalam Novel ini sejalan dengan kasus korupsi dalam novel Mimi Lan Mintuna Karya Remi Silado yang diteliti oleh Basri,dkk dengan artikel yang berjudul Patologi Sosial dalam Novel Mimi Lan Mintuna Karya Remi Silado. Hal tersebut dilihat dari diksi menyuap pejabat. Dalam artikel tersebut diketahui bahwa pejabat yang disuap adalah aparat penegak hukum atau kepolisian. Pada penelitian ini korupsi yang ditemukan, salah satunya juga berbentuk penyuapan kepada pejabat, tetapi dalam novel Rembulan Tenggelam di Wajahmu korupsi dilakukan oleh Koh Cheu sebagai pebisnis dengan pihak pejabat pemerintahan dalam kasus suap pelebaran lahan bisnis.

\section{Bentuk Patologi Sosial: Prostitusi}

Pelacuran atau prostitusi adalah bentuk penyimpangan seksual yang mendapatkan upah. (Burlian, 2016:202). Pelacuran atau prostitusi merupakan salah satu penyakit masyarakat yang masih banyak ditemukan di Indonesia. Pada novel Rembulan Tenggelam di Wajahmu karya Tere Liye ini terdapat bentuk patologi pelacuran. Hal tersebut digambarkan Tere Liye melalui tokoh Fitri. Berikut adalah kutipan yang mewakili salah satu bentuk patologi sosial yaitu protitusi tersebut.

"Aku wanita simpanan. Ya aku wanita simpanan yang menjijikan, memuaskan nafsu bejat lelaki” gadis itu terisak. (Liye, 2018:271)

\section{"Aku menjadi wanita simpanan pejabat, pengusaha, atau siapa saja sepanjang mereka bisa membayar tarifku.” (Liye, 2018: 274)}

Kutipan di atas menggambarkan bentuk patologi sosial prostitusi. Hal tersebut tergambarkan oleh dialog Fitri kepada Ray. Fitri digambarkan oleh pengarang adalah seorang pelacur. Ia mengakui menjadi wanita simpanan pejabat, ataupun pengusaha demi memuaskan nafsu bejat lelaki. Ia melakukan semua itu secara sadar dan tentunya agar mendapatkan uang sebanyak-banyaknya untuk membayar rumah sakit dan biayaa kehidupan sehari-harinya.

Bentuk patologi sosial prostitusi juga dianalisis oleh Basri, dkk dalam novel Mimi Lan Mintuna Karya Remi Silado. Dalam penelitiannya, menunjukkan tindak prostitusi dengan menghadirkan tokoh Indayati. Indayati melakukan syuting film porno secara sadar atas permintaan bosnya. Hasil produksi film tersebut dijual ke majalah Forny agar orang-orang banyak yang berminat memesan Indayati. Hasil penjualan video porno dan pelacuran yang dilakukan Indayati sepenuhnya dikelola oleh Bosnya. Indayati tidak mendapatkan uang sedikit pun untuk dikelolanya sendiri. Ia hanya dijadikan korban dan dijadikan sebagai alat untuk mendapatkan uang dengan cara yang mudah oleh Bosnya. Lain halnya dengan prostitusi yang dilakukan Fitri dalam novel Rembulan Tenggelam di Wajahmu. Dalam novel ini Fitri secara sadar melakukannya dan ia melakukan hal tersebut untuk mendapatkan uang, sehingga pada penelitian ini terdapat perbedaan dari penelitian sebelumnya yang dilakukan oleh Basri, dkk.

\section{IV.SIMPULAN}

\section{SIMPULAN}

Berdasarkan analisis terhadap data yang berkaitan dengan patologi sosial yang terkandung di dalam novel Rembulan Tenggelam di Wajahmu karya Tere Liye, terdapat bentuk-bentuk patologi sosial yang tercermin dari perilaku para tokohnya. Bentuk-bentuk patologi sosial tersebut yaitu kriminalitas, perjudian, minuman keras, korupsi, dan prostitusi. Penelitian ini dilakukan sebagai refleksi sosial untuk menghadapi masalah sosial salah satunya adalah tentang masalah penyakit masyarakat atau dalam istilah ilmu sosiologi disebut patologi sosial. Selain itu hasil penelitian ini dapat merefleksikan diri agar tidak terjerumus dalam bentuk-bentuk patologi sosial.

\section{DAFTAR PUSTAKA}

Anugrah, Yogi. (2019). 10 Hari, 90 Orang Jadi Tersangka Prostitusi, Perjudian, Miras Ilegal, \& Premanisme di Sleman, HarianJogja.com.

Basri, M. H., Mustamar, S., \& Ningsih, S. (2013). Analisis Patologi Sosial dalam Novel Mimi Lan Mintuna karya Remy Sylado. Publika Budaya, Vol.1, No.1, 1-15.

Burlian, Paisol. (2016). Patologi Sosial. Jakarta: Bumi Aksara.

Jamaludin, Adon Nasrullah. 2016. Dasar-dasar Patologi Sosial. Bandung: Pustaka Setia.

Kartono, Kartini. (1991). Patologi Sosial. Jakarta: Rajawali Press.

Liye, Tere. (2018). Rembulan Tenggelam di Wajahmu. Jakarta: Republika.

Moleong, J. (2011). Metodologi Penelitian Kualitatif. Bandung: PT Remaja Rosda Karya.

Nurcahyanti, N., Satrijono, H., \& Husniah, F. (2013). PATOLOGI SOSIAL DALAM WACANA LAGU KARYA SLANK PADA ALBUM PLUR TAHUN 2004. Pancaran Pendidikan, 2(2), 141-148.

Syarif, M. I. (2016). Masalah dan Solusi Patologi Sosial Di Kota Tangerang Selatan. SALAM: Jurnal Sosial dan Budaya Syar-i, 3(2), 121-136. 
Wellek, Rene \& Austin, Warren. (1993). Teori Kesusastraan (Penerjemah: Melani Budianta). Jakarta: Gramedia.

Willis, Sofyan S. 2005. Remaja dan masalahnya: Mengupas berbagai bentuk kenakalan remaja seperti narkoba, free sex dan pemecahannya. Bandung: Alfabeta

Yamin, D. (2016). KEPRIBADIAN TOKOH DALAM NOVEL REMBULAN TENGGELAM DI WAJAHMU. JURNAL BASTRA, 2(1). 